\title{
p53 and bcl-2 expression do not correlate with prognosis in primary cutaneous large T-cell lymphomas
}

Overexpression of p53 protein in cutaneous T-cell lymphoma (CTCL) has been reported in primary cutaneous large T-cell lymphomas (PCLTCL) and has been associated with tumor progression and transformation in mycosis fungoides. However, the prognostic significance of p53 expression has not been studied thus far. In the present study we investigated the expression of p53 as well as bcl-2 protein in 27 PCLTCL, including 19 CD30-positive and $8 \mathrm{CD} 30$-negative lymphomas, retrieved from the registry of the Dutch Cutaneous Lymphoma Working Group.

The results were correlated with follow-up data and proliferative activity, as assessed by the percentage of MIB-1 positive tumor cells.

Overexpression of p53 protein, defined as nuclear staining of more than $5 \%$ of the tumor cells, was found in 10 of 27 cases (37\%), including 6 of 19 (32\%) CD30+lymphomas and 4 of 8 (50\%) CD30-PCLTCL. bcl-2 protein was expressed in 6 of 19 (32\%) CD30+lymphomas and in only 1 of 8 (12\%) CD30-PCLTCL. However, no significant correlation between p53 or bcl-2 expression and prognosis was found, neither in the whole group, nor within the CD30+ or CD30- group. In addition, no relationship between p53 expression and proliferative activity was found. The results confirm that p53 expression is more common in PCLTCL than in mycosis fungoides and Sézary syndrome. However, neither p53 nor bcl-2 expression correlated with survival or proliferative activity.

van Haselen CW, Vermeer MH, Toonstra J, van der Putte SCJ, Mulder PGH, van Vloten WA, Willemze R. p53 and bcl-2 expression do not correlate with prognosis in primary cutaneous large T-cell lymphomas.

J Cutan Pathol 1997: 24: 462-467. (c) Munksgaard 1997.

\author{
Christian W. van Haselen', \\ Maarten H. Vermeer ${ }^{3}$, \\ Johan Toonstra', \\ Sebastian C. J. van der Putte², \\ P. G. H. Mulder', \\ Willem A. van Vloten ${ }^{1}$ and \\ Rein Willemze ${ }^{3}$
}

Depts. of ${ }^{1}$ Dermatology and 2Pathology, University Hospital Utrecht, Utrecht, ${ }^{3}$ Dept. of Dermatology, Free University Hospital, Amsterdam, and ${ }^{4}$ Dept. of Epidemiology and Biostatistics, Erasmus Universiteit, Rotterdam, The Netherlands

Christian W. van Haselen, M.D., Department of Dermatology, University Hospital Utrecht, Heidelberglaan 100, 3584 CX Utrecht, The Netherlands

Accepted March 13, 1997
It has been well established that most cutaneous Tcell lymphomas (CTCL) other than mycosis fungoides (MF) and Sézary syndrome (SS) are large cell lymphomas (1-3). These primary cutaneous large T-cell lymphomas (PCLTCL) represent a heterogeneous group both clinically and histologically.

Previous studies demonstrated that in the PCLTCL group expression of the CD30 antigen on the majority of tumor cells is the most important prognostic parameter. Thus, whereas CD30positive PCLTCL have an excellent prognosis (limited disease, good response to therapy, 4-year survival $>90 \%$ ), the prognosis of CD30-negative
PCLTCL is often poor (early dissemination to extracutaneous sites, frequent relapses during or after therapy, 4-year survival $<25 \%)(4,5)$. The molecular and genetic mechanisms underlying the differences in clinical behaviour between these two groups of CTCL are as yet unexplained.

Recent studies suggested that both p53 and bcl-2 may play an important role in the development and progression of malignant lymphomas (6-8). p53 is a tumor-suppressor gene involved in the transcription of genes that negatively control cell proliferation. Mutations or binding to viral or cellular proteins results in an increased stability and accumula- 
p53 and bcl-2 expression in PCTLTCL

Table 1. Clinical and immunohistochemical data in 19 primary cutaneous CD30-positive and 8 primary cutaneous CD30-negative large T-cell lymphomas.

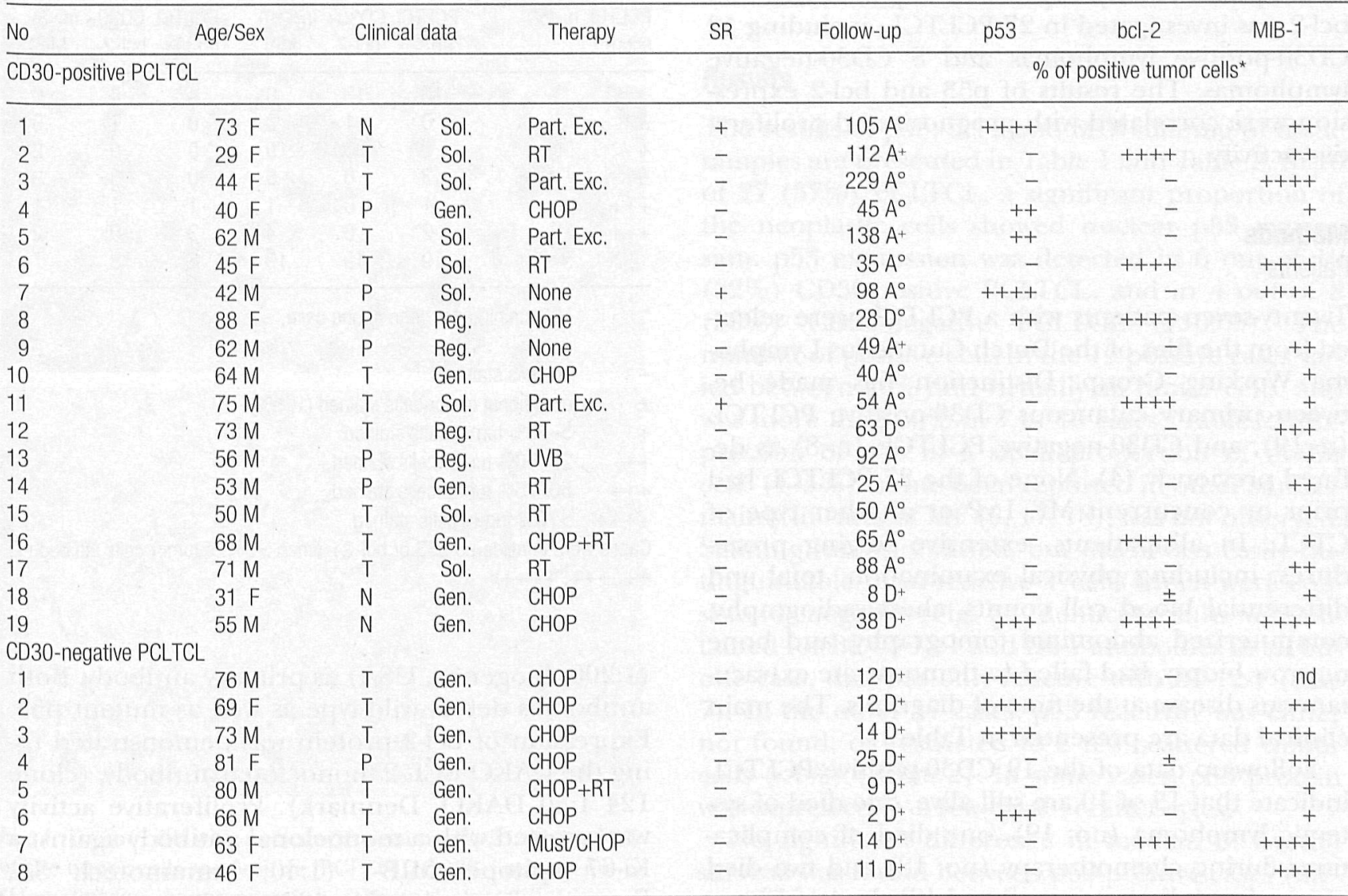

$N=$ nodule

$\mathrm{T}=$ tumor

$P=$ plaque

sol = solitary lesion

reg $=$ regional disease

gen $=$ generalized disease

$\mathrm{SR}=$ spontaneous regression of the disease

$A^{\circ}=$ complete remission

$\mathrm{A}^{+}=$continuing disease

$\mathrm{D}^{\circ}=$ died of unrelated cause

$\mathrm{D}^{+}=$died of systemic lymphoma

$\mathrm{RT}=$ radiotherapy

Part. Exc. = Partial excision

Must $=$ Mustine (mechlorethamine-HCL)

$\mathrm{CHOP}=$ polychemotherapy (cyclophosphamide, adriamycine, vincristine,

prednisone)

tion of p53 protein, which then becomes detectable by immunohistochemistry. Functional inactivation of the p53 gene is the most common defect in human tumors $(10,11)$, and has also been implicated in disease progression and transformation of CTCL (6). However, whereas in B-cell-type non-Hodgkin lymphoma p53 expression was indicative for a poor prognosis (12), the prognostic significance of p53 expression in CTCL is as yet unknown.

bcl-2 protein can prolong cell survival by blocking apoptosis. Overexpression of the bcl-2 gene is
* - no cells stained

\pm occasional tumor cells stained $(1-5 \%)$

$+5-25 \%$ tumor cells stained

$++25-50 \%$ tumor cells stained

$+++50-75 \%$ tumor cells stained

$++++>75 \%$ tumor cells stained observed in a high proportion of both B- and Tcell neoplasms $(8,12)$. It may result from the interchromosomal translocation $14 ; 18$, characteristic of follicular lymphomas, but may also result from other mechanisms (14). In B-cell-type nonHodgkin lymphoma bcl-2 expression was associated with an unfavourable prognosis $(12,13)$. The prognostic value of bcl-2 in PCLTCL has not been studied thus far.

Since a correlation between p53 expression and proliferation activity has been reported (9), MIB-1 
antibody (17) was added as a proliferation marker. In the present study, expression of p53, MIB-1 and bcl-2 was investigated in 27 PCLTCL, including 19 CD30-positive lymphomas and 8 CD30-negative lymphomas. The results of p53 and bcl-2 expression were correlated with prognosis and proliferative activity.

\section{Methods}

\section{Patients}

Twenty-seven patients with a PCLTCL were selected from the files of the Dutch Cutaneous Lymphoma Working Group. Distinction was made between primary cutaneous CD30-positive PCLTCL $(n=19)$, and CD30-negative PCLTCL $(n=8)$ as defined previously (4). None of the 27 PCLTCL had prior or concurrent MF, LyP or another type of CTCL. In all patients, extensive staging procedures, including physical examination, total and differential blood cell counts, chest radiography, computerized abdominal tomography, and bone marrow biopsy, had failed to demonstrate extracutaneous disease at the time of diagnosis. The main clinical data are presented in Table 1.

Follow-up data of the 19 CD30-positive PCLTCL indicate that 15 of 19 are still alive, one died of systemic lymphoma (no. 19), one died of complications during chemotherapy (no. 18) and two died of unrelated disease (nos. 8 and 12). In 4 of 19 cases $(21 \%)$ regression of the lesions occurred, including 2 cases in which regression was induced by partial excision and 2 cases in which regression occurred spontaneously. The median follow-up of this group is 48 months (range, 8-229 months). In the CD30-negative group, all 8 patients died of lymphoma 2 to 25 months after diagnosis (median, 12 months). Median survival in CD30-positive PCLTCL was 63 months and in CD30-negative PCLTCL median survival was 12 months (Table 3 ).

\section{Immunohistochemistry}

Four micrometer sections of formaldehyde-fixed and paraffin-embedded tumor specimens were mounted on poly L-lysine-coated slides and dried overnight $\left(37^{\circ} \mathrm{C}\right)$. Sections were then dewaxed and rehydrated. Endogenous peroxidase activity was blocked by incubation with $0.3 \%$ hydrogen peroxide in methanol. Antigen retrieval was carried out by heating three times (for $5 \mathrm{~min}$ on each occasion) in a microwave oven at 180 Watt in a 10 $\mathrm{mmol} / \mathrm{L}$ citrate buffer at $\mathrm{pH}$ 6.0. Non-specific binding sites were blocked by incubation with normal rabbit serum diluted in phosphate-buffered saline.

Immunostaining of p53 was performed with D07 (1:500; DAKO, Denmark) and Bp53-12-1
Table 2. Expression of bcl-2, p53 and MIB in CD30+/- PCLTCL

\begin{tabular}{|c|c|c|c|c|c|c|}
\hline \multirow{2}{*}{$\begin{array}{l}\text { PCLTCL } n=27 \\
\text { score }\end{array}$} & \multicolumn{3}{|c|}{ PCLTCL CD30+ $(n=19)$} & \multicolumn{3}{|c|}{ PCLTCL CD30- $(n=8)$} \\
\hline & p53 & bcl-2 & MIB & p53 & bcl-2 & $\mathrm{MIB}^{*}$ \\
\hline - & 13 & 12 & 0 & 4 & 6 & 0 \\
\hline \pm & 0 & 1 & 0 & 0 & 1 & 0 \\
\hline+ & 0 & 0 & 9 & 0 & 0 & 2 \\
\hline++ & 3 & 0 & 5 & 0 & 0 & 2 \\
\hline+++ & 1 & 0 & 1 & 1 & 1 & 1 \\
\hline \multirow[t]{2}{*}{++++} & 2 & 6 & 4 & 3 & 0 & 2 \\
\hline & 19 & 19 & 19 & 8 & 8 & 7 \\
\hline
\end{tabular}

$\begin{array}{ll}* & \text { MIB staining not done in one case. } \\ - & \text { no cells stained } \\ \pm & \text { occasional tumor cells stained }(1-5 \%) \\ + & 5-25 \% \text { tumor cells stained } \\ ++ & 25-50 \% \text { tumor cells stained } \\ +++ & 50-75 \% \text { tumor cells stained } \\ ++++ & >75 \% \text { tumor cells stained } \\ \text { Cases were considered } p 53 \text { or bcl- } 2+\text { when }>5 \% \text { of tumor cells stained }(+, \\ ++,+++,++++) .\end{array}$

(1:200; Biogenex, USA) as primary antibody. Both antibodies detect wild-type as well as mutant p53. Expression of bcl-2 protein was demonstrated using the DAKO BCL-2 monoclonal antibody, (clone 124 1:50 DAKO, Denmark). Proliferative activity was assessed with a monoclonal antibody against a Ki-67 epitope, MIB-1 (1:40; Immunotech SA, France). Biotinylated rabbit anti-mouse immunoglobuline (1:500) and streptavidin-biotin horseradish peroxidase complex (1:200) were employed as second and third steps. The peroxidase reaction was visualized using a 3,3 diamino-benzidine-tetrahydrochloride $/ \mathrm{H}_{2} \mathrm{O}_{2}$ (Sigma, St Louis, $\mathrm{MO})$. Positive controls were performed by staining paraffin sections from a p53-positive breast carci-

Table 3. Comparison between CD30-positive and CD30-negative cases

\begin{tabular}{|c|c|c|}
\hline Characteristics & $\begin{array}{c}\text { PCLTCL CD30+ } \\
(n=19)\end{array}$ & $\begin{array}{c}\text { PCLTCL CD30- } \\
(n=8)\end{array}$ \\
\hline Male/Female & $13 / 6$ & $5 / 3$ \\
\hline Age, y (mean $\pm S D)$ & $55 \pm 13$ & $68 \pm 12$ \\
\hline Spontaneous remission & 4 & - \\
\hline \multicolumn{3}{|l|}{ Current status: } \\
\hline complete remission & 12 & - \\
\hline ongoing disease & 3 & - \\
\hline died, not of lymphoma & 2 & - \\
\hline died of lymphoma & 2. & 8 \\
\hline $\begin{array}{l}\text { Survival median ( } 95 \% \text { conf. interval) } \\
\text { in months }\end{array}$ & $63(40-98)$ & $12(2-14)$ \\
\hline 4 years' survival & $86 \%$ & $0 \%$ \\
\hline p53 positive/total cases ${ }^{*}$ & $6 / 19(32 \%)$ & $4 / 8(50 \%)$ \\
\hline bcl-2 positive/total cases* & $6 / 19(32 \%)$ & $1 / 8(13 \%)$ \\
\hline
\end{tabular}

* Cases were considered p53 respectively bcl- $2+$ when $>5 \%$ of the tumor cells stained. 


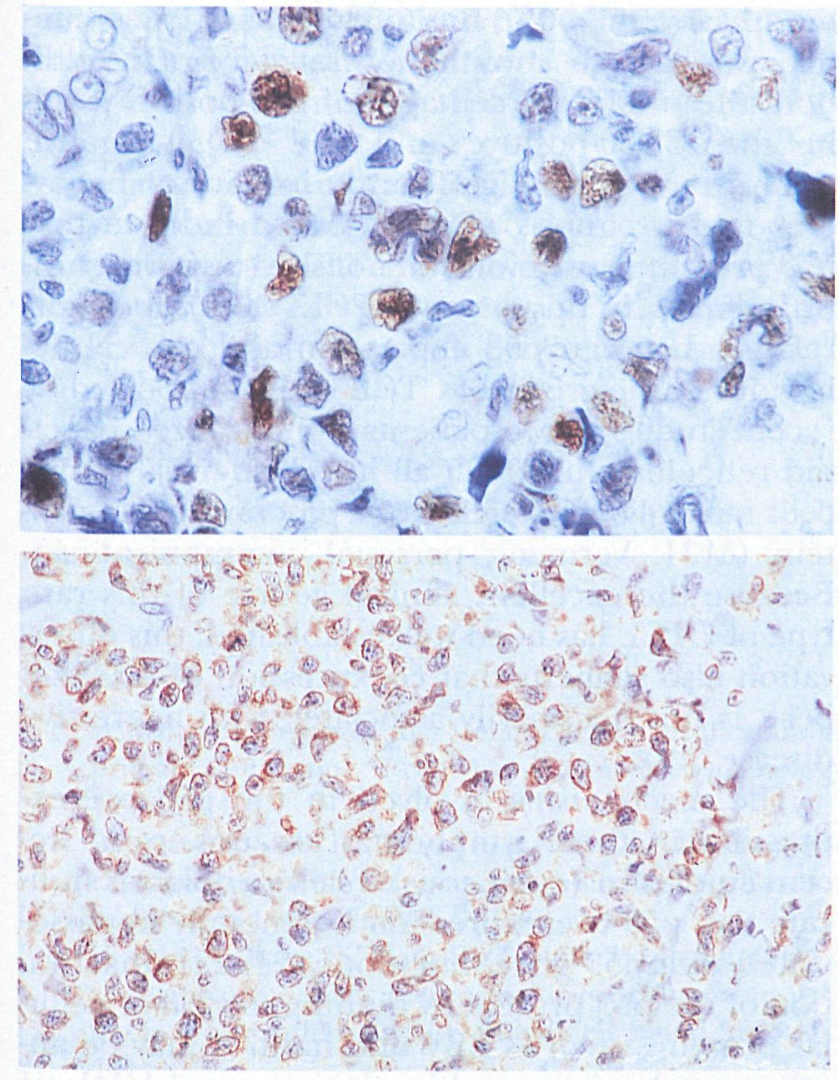

Fig. 1. Tumor cells with nuclear expression of p53. About $50 \%$ of the tumor cells are positive. PCLTCL, CD30-, patient no. 6. (Hematoxylin counterstaining. Original magnification $x$ $1000)$.

Fig. 2. Tumor cells with cytoplasmic expression of bcl-2. Virtually all tumor cells are positive. PCLTCL, CD30+; patient no 16. (Hematoxylin counterstaining. Original magnification $\times 400$ ).

noma. Omission of the first antibody was used as a negative control. All incubations were performed at room temperature.

Immunostaining for p53, bcl-2 and MIB-1 was semi-quantitatively expressed as follows: $-=$ no or very few tumor cells stained $(<1 \%) ; \pm=$ occasional cells stained $(1-5 \%) ;+=$ positivity of $5-25 \%$ of the tumor cells and $++=25-50 \%$ of the tumor cells stained; $+++=50-75 \%$; $++++=>75 \%$ of the tumor cells stained.

\section{Statistical evaluation}

Statistical analysis of clinical data and p53, MIB-1 and bcl-2 expression was performed using multivariate analysis and Cox proportional hazards survival analysis. For this purpose and consistent with other studies (9), patients with more than $5 \%$ p53or bcl-2-positive tumor cells were considered as one group and compared with lymphomas con- taining no or occasional $(<5 \%)$ p53- or bcl2-positive tumor cells.

\section{Results}

The results of p53, bcl-2 and MIB staining of tissue samples are presented in Table 1 and Table 2. In 10 of $27(37 \%)$ PCLTCL, a significant proportion of the neoplastic cells showed nuclear p53 expression. p53 expression was detected in 6 out of 19 (32\%) CD30-positive PCLTCL, and in 4 out of 8 (50\%) CD30-negative PCLTCL $(\mathrm{P}>0.05)$. The number of positive cells in the 10 positive cases varied between $20 \%$ and virtually all tumor cells, and was more than $50 \%$ in 7 of 10 cases (Table 2). Expression of p53 in a small proportion of tumor cells $(1-5 \%)$, as has been reported in other studies, mainly in cases of MF $(9,17,18)$, was not observed. Staining intensity varied, but was always easily distinguishable from reactive $T$ cells which were consistently negative (Fig. 1). Identical results were obtained for BP-53-12-1 and D0-7 antibodies in all but one case, that was only reactive with BP-12-1 (case 7). In the other 17 cases, p53 reactivity was either not found, or restricted to a few scattered tumor cells $(<1 \%$ ) (Table 2 ). In some cases, p53 protein was expressed by a few basal keratinocytes.

No significant difference in median or overall survival was found between p53-positive cases (median survival, 31 months; overall $50 \%$ ) and p53negative cases (median survival, 38 months; overall $55 \%$ ).

In 7 of 27 cases $(30 \%)$, most tumor cells $(>80 \%)$ showed cytoplasmic staining for bcl-2 protein (Fig. 2). bcl-2 expression was found in 6/19 (32\%) CD30-positive PCLTCL, but in only 1 of $8(12 \%)$ (CD30-negative PCLTCL (Table 3). However, the difference in bcl-2 reactivity between the two groups was statistically not significant $(\mathrm{P}>0.05)$. Cox proportional hazard analysis did not differ between the two groups $(\mathrm{P}=0.96 ; 95 \%$ confidence interval 0.252-4.296). In all cases most reactive $\mathrm{T}$ cells showed strong reactivity for bc1-2 protein, serving as a useful internal control.

Staining with MIB-1 antibody was always confined to the nucleus and showed considerable variation in both intensity of staining and the number of positive cells.

The percentage of tumor cells reactive with MIB-1 antibody varied between 5 and $90 \%$ (Table 1). No significant differences were observed between CD30+ and CD30- PGLTCL. In 2 of 27 cases (nos. 8 and 19), the neoplastic T cells expressed both p53 and bcl-2 protein. One of these patients died of unrelated disease 28 months after diagnosis, while the other died of lymphoma after 38 months. 
The proportion of MIB-1 positive cells did not correlate with p53 and bcl-2 expression, nor with survival. Multivariate analysis with bc1-2, p53 and MIB-I did not reveal a correlation with prognostic value.

Spontaneous remission was observed in 4/19 (= $21 \%$ ) of the CD30+ and $0 / 8$ of the CD30- PCLTCL. However, no relationship was found between the occurrence of spontaneous remission and p53, bcl-2 and MIB-1 expression.

\section{Discussion}

In an attempt to unravel the molecular mechanisms underlying the development and progression of cutaneous lymphomas, recent studies have begun to investigate these conditions for the presence of specific translocations and the expression of oncogenes and tumor-suppressor genes. In cutaneous T-cell lymphoma (CTCL) most studies have focused upon expression of the p53 protein. These studies demonstrated consistently negative results in large plaque parapsoriasis (19), lymphomatoid papulosis $(9,18)$, Sézary syndrome $(18,19)$ and patch stage MF (18). Increased numbers of p53-positive tumor cells, but rarely exceeding $5 \%$, were demonstrated in plaque and tumor stage $\mathrm{MF}$ $(9,18)$. Many p53-positive cells were found in 20$50 \%$ of diffuse large cell lymphomas progressing from MF or arising de novo $(6,9,18,20)$. These studies suggested a relationship between p53 expression and tumor progression in CTCL.

However, whether the increased p53 expression in these PCLTCL has also prognostic significance or merely reflects the proliferative activity of the neoplastic cells, has not been studied so far. Therefore, in the present study of 27 PCLTCL, including 19 CD30-positive and 8 CD30-negative lymphomas, the expression of p53 and bcl-2 proteins was investigated and correlated with both survival and proliferative activity.

Expression of p53 protein in more than $5 \%$ of the neoplastic cells was found in 10/27 (37\%) cases (Table 3), which is similar to the results of Lauritzen et al. (9), who noted p53 expression in 8 of $17(47 \%)$ PCLTCL. These percentages are lower than those found in systemic large cell lymphomas, reporting p53 expression in 15/17 (88\%) of the cases (21). Our results also confirm that p53 protein is more frequently expressed in these PGLTCL than in MF and SS.

No major difference in p53 expression was found between CD30-positive and CD30-negative lymphomas ( $32 \%$ versus $50 \%$; $\mathrm{P}>0.05$ ). No difference in median or overall survival was found between p53-positive cases (median survival, 31 months; overall 50\%) and p53-negative cases (median survival, 38 months; overall $55 \%$ ). In addition, the similar percentages of p53-positive cases in the CD30-positive and the CD30-negative group, that differ significantly in clinical behaviour and prognosis (Table 2), also indicate that p53 protein expression can not serve as a prognostic indicator in this group of PCLTCL. Lack of correlation between p53 expression and clinical behaviour in the group of CTCL is also supported by recent studies in two patients with localized pagetoid reticulosis, in which all intraepidermal tumor cells strongly expressed both p53 and bc1-2 protein (M.H. Vermeer; personal communication). Because the excellent clinical course of this rare type of CTCL has been well established, this observation also suggests that coexpression of p53 and bcl-2 is not necessarily associated with aggressive disease (12).

The mechanisms involved in the p53 overexpression in these lymphomas are unknown. Recent studies in (cutaneous) T-cell neoplasms indicate that p53 overexpression is generally not associated with p53 gene mutations $(21,22)$. Inactivation of the p53 protein by binding to viral or cellular proteins, such as EBV and mdm-2, may be another mechanism resulting in increased levels of p53 protein $(23,24)$. However, in non-immunocompromised CTCL patients several studies have failed to demonstrate EBV DNA, RNA and latent membrane protein-l expression $(9,18,19)$. Based on studies of bone marrow blasts, in vitro stimulated lymphocytes and basal keratinocytes in psoriatic epidermis, a correlation between p53 expression and proliferative activity has been suggested (9). Previous studies in MF as well as in nodal nonHodgkin lymphomas demonstrated a positive correlation between the proliferative activity and the grade of malignancy $(26,28)$. In the present study, no correlation was found between the number of p53-positive tumor cells and the proportion of proliferating cells, as assessed by reactivity with MIB-1 antibody.

Studies on bcl-2 expression in CTCL are few, and their results conflicting. In the present study bcl-2 protein was expressed in 6 of 19 CD30-positive PCLTCL and in only 1 of 8 CD30-negative PCLTCL. The clinical and biological significance of bcl-2 expression in these lymphomas is as yet unknown. A correlation between bcl-2 expression and survival was not found. Recent studies demonstrated that the large atypical CD30-positive cells in most cases of LyP also express bc1-2 protein (27). CD30-positive PCLTCL and LyP represent closely related conditions (5). Both have an excellent prognosis and a tendency, though to a varying degree, to resolve spontaneously. Indeed, sponta- 
neous regression was noted in 5 of 19 cases, but a correlation between spontaneous regression and bcl-2 either with p53 or MIB-1 expression was not found.

In conclusion, our results indicate that p53 and bc1-2 proteins are expressed by a considerable proportion of PCLTCL. However, no correlation was found between p53 and bc1-2 expression and clinical behaviour, nor with proliferative activity.

\section{Acknowledgements}

Ms. E. de Vries is acknowledged for excellent technical assistance.

\section{References}

1. Willemze R, Beljaards RC, Meijer CJLM. Classification of primary cutaneous T-cell lymphoma. Histopathology 1994: 24: 405 .

2. Ralfkiaer E, Saati TA, Bosq J et al. Immunohistochemical characterization of cutaneous lymphomas other than mycosis fungoides. J Clin Pathol 1986: 39: 353.

3. Wood GS, Burke JS, Horming S et al. The immunologic and clinicopathologic heterogeneticity of cutaneous lymphomas other than mycosis fungoides. Blood 1983: 62: 464.

4. Beljaards RC, Meijer CJLM, Scheffer E et al. Prognostic significance of CD30 (ki-1/Ber-H2) expression in primary cutaneous large cell lymphomas of T-cell origin. A clinicopathologic and immunohistochemical study in 20 patients. Am J Pathol 1989: 135: 1169.

5. Willemze R, Beljaards RC. Spectrum of primary cutaneous CD30 (ki-1)-positive Iymphoproliferative disorders. J Am Acad Dermatol 1993: 28: 973.

6. Chooback L, Felix CA, Salhany KE et al. Overexpression of P53 protein in cutaneous T-cell lymphoma (CTCL): relationship to large cell transformation and disease progression J Invest Dermatol 1995: 104: 674

7. Lo Coco F, Gaidano G, Louie DC et al. P53 mutations are associated with histologic transformation of follicular lymphoma. Blood 1993: 82: 2289.

8. Pezzella F. The bc12 protein and its gene in hematological and epithetical tumors. In: Polli EE, ed. Molecular basis of human disease. Amsterdam: Excerpta Medica, 1993: 241.

9. Lauritzen AF, Vejlsgaard GL, Hou-Jensen K, Ralfkiaer E. $\mathrm{P} 53$ protein expression in cutaneous T-cell lymphoma. $\mathrm{Br}$ J Dermatol 1995: 133: 32.

10. Hollestein M, Sidransky D, Vogelstein B, Harris CC. P53 mutations in human cancer. Science 1991: 253: 49.

11. Levine AJ, Momand J, Finlay CA. The p53 tumor suppressor gene. Nature 1991: 351: 453.

12. Piris MA, Pezzella F, Martinez-Montero JC et al. P53 and bcl2 expression in high-grade B-cell lymphomas; correlation with survival time. Br J Cancer 1994: 69: 337.

13. Hermine O, Haioun C, Lepage E et al. Prognostic significance of bcl2 protein expression in aggressive non-Hodgkin's lymphoma. Blood 1996: 87: 265.1
14. Pezzella F, Tse AGD, Cordell JL. Expression of the bcl2 oncogene protein is not specific for the $14 ; 18$ chromosomal translocation. Am J Pathol 1990: 137: 225.

15. Rose DSC, Maddox PH, Brown DC. Which proliferation markers for routine immunohistology? A comparison of five antibodies. J Clin Pathol 1994: 47: 1010.

16. Holden JA, Perkins SL, Snow GW, Kjeldsberg CR. Immunohistochemical staining for DNA topoisomerase II in non-Hodgkin's lymphomas. Am J Clin Pathol 1995: 104: 54.

17. Kanavaros P, Ioannidou D, Tzardi M et al. Mycosis fungoides: Expression of C-myc P62, P53, bcl2 and PCNA proteins and absence of association with Epstein-Barr virus. Path Res Pract 1994: 190: 767.

18. McGregor JM, Dublin EA, Levison DA et al. P53 immunoreactivity is uncommon in primary cutaneous lymphoma. BrJ Dermatol 1995: 132: 353.

19. Beylot Barry M, Vergier B, De Mascarel et al. P53 oncoprotein expression in cutaneous lymphoproliferations. Arch Dermatol 1995: 131: 1019.

20. Van Haselen CW, Toonstra J, Van der Putte SCJ, Van Vloten WA. Diminished apoptosis of tumor cells in large cell cutaneous T-cell lymphomas. Consequences for cell biological behaviour and therapy resistance. In: Pieters $\mathrm{P}$, Kaspers GJL, Veerman AJP, eds. Drug resistance in leukaemia and lymphoma. Singapore: Harwood Academic Publishers, 1996: 129.

21. Cesarman E, Inghirami G, Chadburn A, Knowles DM. High levels of p53 protein expression do not correlate with mutations in anaplastic large cell lymphoma. Am J Pathol 1993: 143: 845.

22. Neri A, Fracchiolla NS, Roscetti E et al. Molecular analysis of cutaneous B- and T-cell lyrnphomas. Blood 1995: 86: 3161 .

23. Szekely L, Selivanova G, Magnusson KP et al. EBNA-5, an Epstein-Barr virus-encoded nuclear antigen, binds to the retinoblastoma and p53 proteins. Proc Natl Acad Sci USA 1993: 90: 5455 .

24. Momand J, Zambetti GP, Olson DC et al. The mdm-2 oncogene product forms a complex with the $\mathrm{p} 53$ protein and inhibits p53 mediated transactivation. Cell 1992: 69: 1237.

25. Lopa TEG. Infrequent association of Epstein Barr virus with CD30 positive anaplastic large cell lymphoma. Am J Surg Pathol 1995: 19: 42.

26. Kaudewitz P, Szeimies RM. Proliferation activity in skin lesions of mycosis fungoides: prognostic and pathophysiologic implications. In: Lambert WC, Gianotti B, van Vloten WA, eds. Basic mechanisms of physiologic and aberrant lymphoproliferation in the skin. New York: Plenum Press, 1994: 317.

27. Orchard GE, Whittaker S, Trotter M and Smith NP. Lymphomatoid papulosis: an immunohistochemical analysis of CD30 positive atypical cells. Br J Dermatol 1995: 45 (suppl): 56 .

28. Korkolopoulou P, Oates J, Kittas C, Crocker J. P53, c-myc p62 and proliferating cell nuclear antigen (PCNA) expression in non-Hodgkin's lymphomas. J Clin Pathol 1994: 47: 9. 
This document is a scanned copy of a printed document. No warranty is given about the accuracy of the copy. Users should refer to the original published version of the material. 